\title{
The Policy of Primary Needs Assistance for the Economic Independence of the Poor Community of Makassar (Case Study of Recipients of the Family Hope Program)
}

\author{
Husain AS M, $\mathrm{Pd}^{1}$ \\ ${ }^{1}$ Lecturer of STKIP Indonesian Development), Indonesia \\ Correspondence: Dr. Husain AS M, Pd, Lecturer of STKIP Indonesian Development, Indonesia.
}

Received: November 24, 2021

Accepted: December 16, 2021

Available online: December 29, 2021

doi:10.11114/ijsss.v10i1.5433

URL: https://doi.org/10.11114/ijsss.v10i1.5433

\begin{abstract}
The research uses qualitative research through a case study approach, while the results of the research are that basic needs assistance for the poor in the family hope program has not been able to improve the community's economy both in the short and long term, there is a mindset that assumes that being poor is a good thing. because they will often receive assistance from the government or from entrepreneurs, for that eradicating poverty must be accompanied by changing people's mindsets so that they can be more creative in dancing sources of income and cultivating shyness in getting help while physically strong
\end{abstract}

Keywords: policy, needs, independence, poor, Makassar

\section{Introduction}

The government has a responsibility in providing community welfare, where the responsibility is in the form of public policy, the condition of Indonesia as a developing country certainly cannot be separated from poverty, especially in the city of Makassar where the majority of the population who has a variety of jobs have little income so they are unable to meet the needs of life. Every day, this condition has an impact on meeting the needs of life, both primary and secondary needs, many problems in the people of Makassar city ranging from legal issues, education issues, criminal acts, fraud, corruption, and others, this is due to insufficient income, while the needs of life continue to increase, the Makassar city government must provide solutions in the form of public policies so that people do not become poor

Makassar City as one of the cities that has a population above one million is a population of various tribes and ethnicities including the Bugis, Mandar, Makassar, Toraja, and several tribes from outside South Sulawesi, their presence with various activities both as traders, employees, businessmen and people who are studying at various universities in the city of Makassar, the dense competition and activities make them have to compete both in the world of education, competition in trade and the office,

The tight competition in life in the community results in many people being unable to compete, so many people work not according to the skills they have, this has an impact on income levels and job satisfaction, many people are unable to provide a living for their families, both in terms of food nutrition, education, and housing. In addition, one of the factors that cause the poverty rate to remain high is the poor character of the community, namely claiming to be poor. When there is food aid from the government, it is not uncommon for poor people who need assistance to be unable to participate in the program. This happens because there is still no optimal coordination between the elements involved in poverty alleviation, both from the community and the government.

\section{Formulation of the Problem}

1. How is the Effectiveness of Basic Needs Assistance (Primary) on the Community Economy in Makassar City

2. What is the strategy for developing the economy of the poor in Makassar

\section{Literature Review}

\section{A. Public Policy}

Public policies are decisions that are binding on the people at a strategic or outline level made by public authorities. As 
decisions that bind the public, public policies must be made by political authorities, namely, those who receive a mandate from the public or the people, generally through an electoral process to act on behalf of the people. Furthermore, public policies will be implemented by the state administration which is run by the government bureaucracy. The main focus of public policy in a modern state is public service, which is everything the state can do to maintain or improve the quality of life of the people. Balancing the role of the state which should provide public services with the right to collect taxes and levies, and on the other hand balancing various groups in society with various interests and achieving the constitutional mandate.

Every political system produces public policy. And the political system can be in the form of a state, province, district/city, village, even RT and RW. "Institutions" such as ASEN, EU, UN, and WTO are political systems too, which can be called supra-states. Public policy is not always carried out by the bureaucracy (only), but can also be implemented by private companies, NGOs, or the public directly. For example, a political system may decide to eradicate mosquitoes. The political system can govern - with compensation of course - a private company to do the mosquito spraying.

The term public policy refers to a wider set of implementing tools than laws and regulations, including aspects of the budget and implementing structure. The public policy cycle itself can be related to policymaking, policy implementation, and policy evaluation. How public involvement in every stage of policy can be a measure of the level of state compliance with the mandate of the people who are sovereign over it. Can the public know what is on the policy agenda, namely a series of issues to be resolved and their priorities, can the public provide input that will influence the content of public policies that will be produced. Likewise at the implementation stage, can the public monitor implementation deviations, as well as whether there is a public control mechanism, namely a process that allows public objections to a policy to be discussed and have a significant effect.

Public policy refers to the wishes of the ruler or government which ideally in a democratic society is a reflection of public opinion (public opinion). To realize this desire and make the policy effective, several things are needed: first, the existence of legal instruments in the form of laws and regulations so that the public can know what has been decided; secondly, this policy must also have a clear implementation and financing structure; third, there is a need for public control, namely a mechanism that allows the public to know whether this policy in its implementation has experienced deviations or not.

In an authoritarian society, public policy is the desire of the rulers alone, so the above description does not work. But in a democratic society, what often becomes a problem is how to absorb public opinion and build a policy that has public support. The ability of political leaders to communicate with people to accommodate their wishes is one thing, but equally important is the ability of leaders to explain to people why a wish cannot be fulfilled. It is naive to expect that there is a government that can satisfy the entire population at all times, but it is authoritarian a government that does not take seriously the aspirations and tries to communicate the policies that it is running and those that will be implemented. In another approach, public policy can be understood by separating its two major conceptions, namely policy, and public. Policy terminology can be interpreted as a choice of action among some available alternatives. meaning that the policy is the result of weighing to then choose the best from the available options. in the macro context, this is then raised in the decision-making portion. Charles Lindblom is an academic who states that policy is closely related to decision-making. Because in essence, both choose between the available options. While public terminology shows an extraordinary breadth to be defined. but in this case, we can at least say that the public is closely related to the state, market, and civil society. it is they who later become actors in the public arena. so that the public can be understood as a dimensional space that shows the interaction between the three actors.

William N. Dunn (2000) suggests that policy analysis is an applied social science discipline that uses a variety of research methods and arguments to generate and transmit policy-relevant information so that it can be utilized at the political level to solve policy problems. Weimer and Vining, (1998:1): The product of policy analysis is advice. Specifically, it is advisable that inform some public policy decisions. So public policy analysis is more of an advice or consideration for public policymakers which contains the problems faced, the tasks that must be carried out by public organizations related to these problems, and also various alternative policies that might be taken with various assessments based on policy objectives.

\section{B. Teori Vicious Circle of Poverty}

The causes of poverty according to Kuncoro (2000) are as follows:

1. On a macro level, poverty arises because of the unequal pattern of resource ownership that results in an unequal distribution of income, the poor only have limited resources and their quality is low.

2. Poverty arises due to differences in the quality of human resources because the quality of human resources is low which means that their productivity will also be low, the wages are also low.

3. Poverty arises because of access to capital. 
The three causes of poverty lead to a vicious circle of poverty, see Figure 2.1. The logic of thinking put forward by Nurkse as quoted by Kuncoro (2000) states that a poor country is poor because it is poor (a poor country is poor because it is poor). Inputting forward his theory of the cycle of poverty, Nurkse essentially argues that poverty is not only caused by the absence of past development but is also caused by obstacles to development in the future. About this, Nurkse said: "A country is poor because it is a poor country" (A country is poor because it is poor).

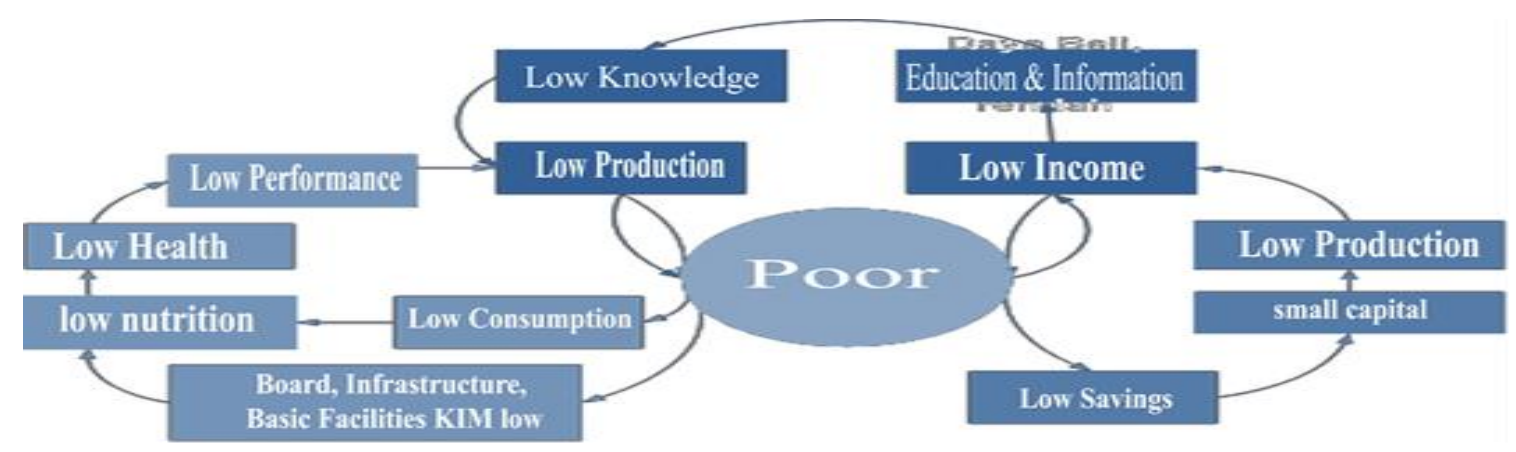

Gambar 2.1. Vicious Circle of Poverty

Source: Nurkse (1953) in Kuncoro, 2000

In his opinion, the essence of the cycle of poverty is the conditions that cause obstacles to the creation of high capital formation. On the one hand, capital formation is determined by the rate of saving and on the other by incentives to invest. In developing countries, these two factors do not allow the implementation of high levels of capital formation. So, according to Nurkse's view, there are two types of cycles of poverty that prevent developing countries from achieving rapid development, namely. In terms of supply of capital and demand for capital.

In terms of the supply of capital, the poverty circle can be stated as follows. The level of people's income is low due to low levels of productivity, causing people's ability to save to be also low. This will cause a country to face a shortage of capital goods and thus its productivity level will remain low which will affect poverty.

\section{Research Methods}

Types of qualitative research through a phenomenological approach

\section{Discussion}

\section{A. Effectiveness of Basic Needs Assistance (Primary) on Economic Independence of the Poor in Makassar City}

The assistance provided by the government in the form of rice, eggs, indomie, cooking oil, and so on is very helpful for the poor, the forms of assistance provided are varied. In handling poverty, the government assists joint business groups in the amount of Rp. 10,000,000 to be managed into business capital, the profits from the business will be divided among group members, this business group receives guidance from the Makassar city government.

To maximize poverty alleviation, the government is trying to make poverty alleviation programs including cash direct assistance programs, where the initial concept is that they are given funds for basic needs, but the reality is that many of these aids are misused and not well-targeted and many recipients of aid misuse the aid towards other needs. While the working capital assistance program to small traders in the form of money also uses this assistance for personal needs and the need for purchasing household equipment, so this concept fails and their business does not progress due to the lack of working capital funds, while the concept of The hope house made by the government in the form of providing 10 liters of rice, 15 eggs, cooking oil, milk and education funds is not optimal and is only able to cover $10 \%$ of the family's needs.

According to the results of an interview with Mrs. Tanty, one of the heads of the recipient group for families of hope in the village of Ballaparang, RW 6 RT 2, said as follows: the aid package in the form of necessities and cash provided by the government has not been maximized in the welfare of the community, meaning that the community remains poor and difficult because assistance is not provided. enough for their families. (interview October 1, 2021)

Various programs made by the government until now have not been able to turn society into a developed society, meaning that if other countries, the people of developed countries have thought a lot about how to develop technology, human resources, then in Indonesia, especially in the city of Makassar, the majority of the population still thinks about fulfilling 
their needs. daily life.

The Makassar city government through its appointed representative, namely the social service, needs to make a planning strategy so that the various programs that are made can run and according to the goals that have been set, the concept of poverty alleviation is not an easy thing because of the many interrelated factors, for that we need-based assistance. community needs and empowerment, this concept must be controlled, not only handing over aid but must be properly monitored from the aspect of aid distribution, guidance, and supervision, according to one academician Dr. Patta Rapanna said as follows: handing over aid to the poor must be accompanied by changing people's mindsets and cultivate a culture of shame in receiving assistance at a productive age

\section{Weaknesses of Poverty Reduction Policies}

The various weaknesses of the current poverty reduction program are as follows:

1. The program has not become the main solution to the causes of poverty faced by poor groups/people.

Poverty is a multidimensional and complex political, social, economic, and cultural phenomenon that has unique and specific characteristics. It is said to be unique because it has three characters. First, the causes of poverty are not the same between regions or from one village to another. Second, each group of poor people living in the village has specific causes of poverty that they face. Third, poverty is also a socio-economic and political, and cultural phenomenon, which is not merely a regional phenomenon. These three characters are less of a paradigmatic basis in policy and in implementing current poverty reduction programs.

2. The main target of the policy (program) is the region and the wider community.

This causes the program to spread to the community sporadically, and not to the poor because the program is not specific to the poor, but the wider community. The broad meaning indicates that empowerment-based programs are not specifically intended for the poor, but rather for the community. So that the programs provided are less able to answer the problems faced by the poor. Ideally, a program is structured based on the causes of poverty faced by groups of poor people.

3. The program does not reach empowerment for the target group

The lack of empowerment concepts from PNPM Mandiri, PUAP, and PPIP-causes weak innovation in formulating programs to reduce poverty. This is reflected in the program's concentration on building things that are not the main objectives, such as building alleys in the village or roads in the middle of rice fields but leaving the main substance to empower the poor at the village level.

\section{Empowering" is synonymous with giving a little income}

This program is not a solution, because the program must be encouraged and directed to give birth to an economic and social capability (capability) for the poor. This process is only possible when access to capital is opened and made easier for the poor. In practice, it is difficult for the poor to access capital because of the requirement that the party entitled to obtain capital is a group of people who already have "start-up capital". Meanwhile, one of the poor people is characterized by a lack of capital. How can there be requirements (obligatory requirements for the poor) when they will access program funds that are used for capital or establishing a business.

5. Determining the character of poverty and the poor should ideally be the main indicator of determining a program to reduce poverty.

Current poverty programs in rural areas are too burdened with development tasks that are not the responsibility of the program. For example, the construction of roads, irrigation, culverts which absorb $75 \%$ of program funds, cause the substance of poverty experienced by the poor to receive less financial assistance. This burden should not be the main element of the program but should be the social and political responsibility of the local government. With this way of thinking, program funds can be directed towards empowering the poor. This priority is not the main objective of poverty reduction programs at the village level, especially PNPM Mandiri, PUAP, and PPIP.

\section{A. Overcoming the Fundamental Weaknesses of Poverty Reduction Policies (Programmes)}

To overcome the fundamental weaknesses of the poverty reduction policy in rural areas as described previously, a limited form of policy (affirmative policy) is needed, by revitalizing the existing paradigm, direction, and strategy for poverty reduction policies in rural areas. Therefore, this model offers a paradigm shift, strategy, and approach to renew the existing poverty reduction policy (program) foundation. In addition, this model offers a change in the main target in overcoming poverty, namely the poor group/people.

\section{B. Assistance for consumption needs for the economic independence of the people of Makassar}

Poverty is an issue that must get attention for the local government of the city of Makassar to immediately maximize its 
role, especially in making strategic planning in poverty alleviation.

The Rumah Harapan program is a program created by the government that aims to minimize poverty in the city of Makassar, according to

The results of an interview with one of the Pkh Chairs (recipients of families of hope) Pkh leaders: tamamau sub-district (panakkukang sub-district) Mrs. Halima I have served for 3 years, coordinated members are 30 families (30 families) There are $500 \mathrm{pkh}$ recipients, there are 10 heads 30 , there are 20 tasks for the chairperson to facilitate assistance and assist, in addition to data collection, to see and monitor when conditions are established, food is issued as a member of the Pkh, assistance is given in the form of necessities (consumption needs).

Meanwhile, according to an interview with Mrs. Raeny, one of the community leaders said as follows: that the Pkh Program is very helpful, only many are not right on target, for example, some are not eligible and those who need it do not receive it. 200,000 per quarter ) Up to 225000 Junior high school 42500 Senior high school 625000 Hallain's mother Monthly assistance in the form of necessities other than that

In addition, they get 200 thousand assistance. The value is 200 thousand, given in the form of $10 \mathrm{~kg}$ of rice, one shelf of eggs, then chicken meat sometimes also fish ( 2 milkfish) presto, distributed in the form of a pkh stall (some are managed i.e. the chairperson) I think it's okay $10 \mathrm{~kg}$, the important thing is that the assistance is evenly distributed, under normal conditions Pkh community members have other activities. The Hope House program activity deserves to be maintained because it involves the livelihood of many people. Conditions for Pkh recipients must have children who are still in school. There are more than 10 hopeful families that should be evaluated every year to see whether their condition is still feasible to be maintained as recipients of the family of hope or not According to Mrs. Nuraeni (community leader) in the Panakkukang sub-district, Makassar City: said the Hope House program was running smoothly, the assistance was smooth. the poor don't get help, the ones who don't deserve it If they get help, when confirmed, they say that the data is from the center, there is also that after receiving the assistance, they use it for business capital. Both according to Mrs. Halima and Mrs. Nuraeni, suggested that the assistance should be given according to, ideally $20 \mathrm{~kg}$ of rice and 2 shelves of eggs, In addition to minimizing and suppressing To reduce poverty, the government should open employment opportunities, encourage entrepreneurship, provide working capital

The amount of assistance provided by the Makassar city government should be accompanied by efforts to change people's mindsets, so far there is an understanding held by the community that by being poor people will often receive assistance in the form of basic consumption assistance, as well as assistance in housing facilities, clean water free health, free education, business capital assistance, and others, this condition will result in a sense of laziness and dependence so that in the long term they will not be productive and tend to be ignorant, besides the concept of empowerment where the economically weak community is given training, capital work and assisted in the distribution of their business marketing so that in the long term they can be creative and no longer depend on assistance from the government

\section{Conclusion}

Poverty alleviation requires cooperation from all components of the nation, both support from the government, the private sector, and the world of education, the complexity of the problem of poverty is a challenge for the Makassar city government, the concept of assistance provided should be accompanied by the formation of human resources, which is expected to gradually open up thinking horizons. about the culture of shame when receiving assistance while physically still productive, changes in mindset and creativity need to be encouraged and recorded in an educational setting that provides education about the importance of being a creative person in finding opportunities and activities that can generate additional income,

\section{References}

Aath-Tawil. (1985). Poverty and Underdevelopment in Muslim Countries translated by Muhammad Bagi.; click .1. Bandung: Mizan,

Adams, R. (2004). Economic Growth, Inequality and Poverty: Estimating the Growth Elasticity of Poverty. World Development, 32(12). The World Bank. Washington DC. https://doi.org/10.1016/j.worlddev.2004.08.006

Aditya, N. P. S. (2010). Analysis of Inequality between Regions and Factors Affecting It with the Panel Data Model (Case Study 35 Regency/City in Central Java Province 2000-2007). Unpublished Thesis. Faculty of Economics, Diponegoro University, Semarang.

Agus, S. (2009). Reducing Poverty; A New Proposal for Indonesia. Makassar: Nala Cipta Litera.

Ahmed, A. (2002). Basic Social Sciences. Jakarta: Renika Cipta. 2003. Basri, Faisal. Indonesian economy. Jakarta : Erlangga. 2002.

Alawi, N. (2006). The Effect of Regional Development Budget on Poverty Case Study: Districts/Cities in Central Java 
2002-2004.

Arsyad, L. (1999). Development Economics. Yogyakarta: STIE YKPN. Central Bureau of Statistics. 2011. Analysis of HDI South Sulawesi Province. South Sulawesi.

Bappeda of South Sulawesi Province. 2013. Study of the Results of Calculation of GRDP of Regency/City of South Sulawesi in 2013. South Sulawesi.

Baswir, R. (1997). People's Economy Agenda. Student library. Yogyakarta.

Efendi, T. N. (1993). Human Resources, Job Opportunities and Poverty. Yogyakarta: Student Library.

Huda, N. et al. (2015). Islamic Development Economics. Jakarta: Prenadamedia Group. 2015.

Meleong, L. J. (1994). Qualitative Research Methodology. Bandung : PT Youth Rosdakarya.

Ministry of Religion of the Republic of Indonesia. Al-Quran and Translation. Jakarta: WALI. 2013.

Setiadi, E. M., \& Usman, K. (2011). Introduction to Sociology. Jakarta: Prenamedia Group, 2011.

South Sulawesi News, Makassar Poor Population Data 2015-2017. Retrieved from http://berita-sulsel.com/2017/03/31/data-sum-penresident-makassar-2015-to-2017/(26October 2017)

Sudarwati, N. (2009). Poverty Alleviation Policy Reducing Poverty Unemployment. Malang: Intimedia. 2009.

Sumar'in, Islamic Economics: An Approach to Microeconomics Perspective of Islamic Economics, Yogyakarta: Graha Ilmu. 2013.

Suparlan, P. (2007). Poverty in Urban. Jakarta: Indonesia Torch Foundation. 1995. Suwarsono, Sri Edi. About Poverty and Justice. Jakarta: Scholar on Islam UI Press. 2007.

\section{Copyrights}

Copyright for this article is retained by the author(s), with first publication rights granted to the journal.

This is an open-access article distributed under the terms and conditions of the Creative Commons Attribution license which permits unrestricted use, distribution, and reproduction in any medium, provided the original work is properly cited. 